Tinjauan Pustaka

\title{
Diagnosis dan Penatalaksanaan Laringomalasia
}

\author{
Elfianto, Novialdi
}

\begin{abstract}
Abstrak
Latar belakang: Laringomalasia (LM) merupakan penyebab tersering stridor inspirasi kongenital pada bayi. Sekitar $80 \%$ kasus merupakan derajat ringan dan sedang yang dapat membaik serta resolusi sampai usia 2 tahun sedangkan 20\% merupakan derajat berat yang membutuhkan tindakan pembedahan Tujuan: Mengetahui dan memahami etiologi, diagnosis dan penatalaksanaan laringomalasia. Tinjauan Pustaka: Diagnosis laringomalasia dapat ditegakkan dari anamnesis, pemeriksaan fisik serta pemeriksaan penunjang laringoskopi serat optic fleksibel. Etiologi pasti laringomalasia belum diketahui, namun terdapat 3 teori yang diduga berperan yaitu imaturitas kartilago, imaturitas neuromuskular dan abnormalitas anatomi. Terdapat hubungan antara laringomalasia dengan laryngopharyngeal reflux (LPR). Penatalaksanaan konservatif dilakukan pada LM derajat ringan dan sedang sedangkan tindakan pembedahan dilakukan pada derajat berat, laringomalasia dengan komorbid dan laringomalasia yang gagal terapi konservatif. Kesimpulan: Laringomalasia merupakan kolapsnya struktur supraglotis ketika inspirasi yang mengakibatkan adanya stridor inspirasi. Laringomalasia derajat berat dapat mengancam nyawa. Sebagian besar kasus akan resolusi sendiri, namun sekitar $20 \%$ memerlukan tindakan pembedahan. Supraglottoplasti merupakan tindakan pembedahan pilihan untuk kasus laringomalasia
\end{abstract}

Kata kunci: Laringomalasia, stridor inspirasi, laringoskopi serat optik fleksibel, supraglottoplasti

\begin{abstract}
Background : Laryngomalacia (LM) is the most common cause of inspiration stridor in infant. About $80 \%$ cases are mild and moderate that can improvement and resolution by 2 years of age, and aboout $20 \%$ cases is severe that need surgical intervention. Objective : Knowing and understanding etiology, diagnosis and management of laryngomalacia. Literature review :. Diagnosis of laryngomalacia is obtained from the history, phisical examination and supporting examination such as flexible fibreoptic laryngoscopy (FFL). The etiology was unknown, but there are some theory that can explain cause of laryngomalacia such as cartilage immaturity, neuromuscular immaturity, an anatomic abnormality. There is corelation between laryngomalacia and laryngopharingeal reflux disease (LPR). Conservative treatment choosing for mild and moderate laryngomalacia and surgical intervention perform for severe laryngomalacia, laryngomalacia with comorbid disease and laryngomalacia which failed with conservative treatment. Conclusion : Laryngomalacia is a condition of supraglottic structure collaps into the airway during inspiratory phase that produce inspiration stridor and can make life threatening. Most of the cases are self limiting resolution, only about $20 \%$ need surgical intervention. Supraglottoplasty is the choice surgical procedure for laryngomalacia.
\end{abstract}

Keywords: Laryngomalacia, inspiration stridor, flexible fibreoptic laryngoscopy, supraglottoplasty

Affiliasi penulis : Bagian THT-KL RSUP dr. M Djamil/Fakultas Kedokteran Universitas Andalas

Korespondensi : Elfianto [adekelfianto.md@gmail.com] Telp: +62 75137194

\section{PENDAHULUAN}

Laringomalasia (LM) merupakan keadaan yang menggambarkan kolapsnya struktur supraglotis laring selama inspirasi sehingga mengakibatkan menyempitnya aliran udara selama inspirasi. ${ }^{1-4}$ Sekitar 60-75\% kasus stridor kongenital disebabkan oleh LM. ${ }^{2,3}$ Istilah laringomalasia pertama kali diperkenalkan oleh Jackson dan Jackson pada tahun 1942 untuk menggambarkan stridor inspirasi kongentital akibat kolapsnya struktur laring saat inspirasi dimana kejadian ini tidak ditemukan pada stridor inspirasi kongenital lainnya. 5,6

Angka kejadian LM di dunia belum diketahui secara pasti, namun lebih banyak ditemukan pada anak laki-laki sebanyak $58-76 \%$ kasus, dan tidak terdapat predileksi terhadap ras tertentu. ${ }^{2}$ Menurut data rekam medis RS Hasan Sadikin Bandung mulai Januari 2012 sampai Maret 2015 terdapat 84 kasus LM (55 kasus laki-laki dan 29 perempuan). ${ }^{7}$

Laringomalasia mempunyai karakteristik stridor yang timbul dalam dua minggu pertama kehidupan sampai beberapa bulan kehidupan bayi. Stridor pada pasien LM dipengaruhi oleh aktivitas, akan timbul ketika bayi menangis, posisi tidur telentang, saat menyusu, infeksi saluran nafas atas dan saat marah. ${ }^{1,8,9}$ Sekitar $80 \%$ kasus laringomalasia merupakan kasus ringan dan sedang yang membaik setelah 8-12 bulan serta resolusi dan sembuh setelah 12-24 bulan, namun $10-20 \%$ dari kasus merupakan derajat berat yang mengancam nyawa dan membutuhkan tindakan operasi segera. ${ }^{3,6,10}$ Penyebab pasti dari laringomalasia ini masih belum diketahui, namun terdapat beberapa teori yang diduga menjadi 
patogenesis LM yaitu teori imaturitas kartilago, abnormal anatomi dan imaturitas neuromuskular. ${ }^{11}$

\section{Anatomi}

Laring merupakan kompleks organ yang berfungsi sebagai sfingter pada pertemuan antara saluran cerna dengan saluran nafas dan berperan penting dalam proteksi saluran nafas, pernafasan dan fonasi. Dalam menjalankan fungsi ini, struktur eksternal dan internal laring bekerja dibawah kontrol persarafan. ${ }^{12}$ Bagian paling atas dari laring adalah epiglottis yang bergerak posterior ke arah faring. Pada bagian dalam, glotis terlihat seperti segitiga yang terbuka ketika inspirasi dan menutup ketika fonasi. Pada daerah glotis terdapat pita suara asli (plika vokalis) dan superolateral dari pita suara asli terdapat pita suara palsu (plika ventrikularis). Posterior glotis dibentuk oleh sepasang kartilago arytenoid yang merupakan perlekatan posterior dari plika vokalis dan plika ventrikularis. Buka dan tutup glotis merupakan koordinasi otot yang menggerakkan aritenoid. Ariepiglotis fold merupakan daerah mukosa yang berada antara aritenoid dan epiglottis. Ariepiglotis fold ini memisahkan sinus piriformis dengan glotis (gambar 1). ${ }^{13}$
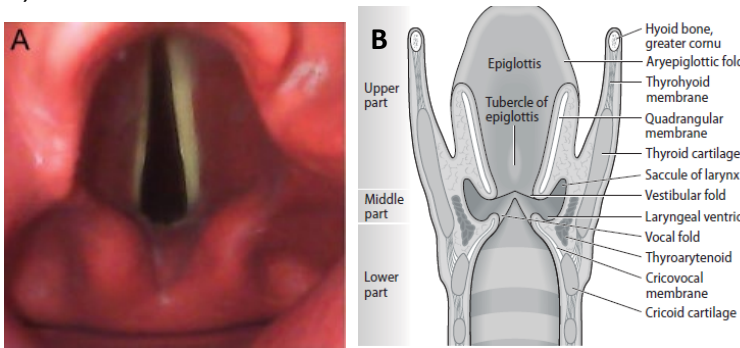

Gambar 1. Anatomi laring. A.Laring dilihat dari superior B. Laring potongan koronal dilihat dari posterior. ${ }^{14,15}$

\section{Etiopatogenesis}

Etiologi pasti dari LM sampai sekarang masih belum diketahui. Terdapat beberapa teori yang menjelaskan tentang penyebab LM, yaitu teori imaturitas kartilago, abnormal anatomi dan imaturitas neuromuskular (gambar 2). ${ }^{11,16}$

\section{Imaturitas Kartilago}

Teori ini pertama kali dikenalkan oleh Sutherland and Lack pada akhir abad ke-19.Menurut teori ini flaksiditas dari laring diakibatkan oleh terlambatnya maturitas kartilago yang membentuk laring. ${ }^{11}$ Teori ini kemudian tidak begitu diterima karena pemeriksaan histologi kartilago pada pasien LM yang mempunyai gejala menunjukkan jaringan kartilago dengan fibro elastin yang normal. ${ }^{9,11}$

\section{Abnormalitas Anatomi}

Menurut teori ini, laringomalasia diakibatkan oleh terdapatnya jaringan laring yang berlebihan pada bayi. Laring pada bayi lebih lunak dan lebih rentan mengalami edema mukosa. Sering didapatkan epiglotis yang omega shapednya menghilang (tubular shape), adanya jaringan /mukosa yang berlebihan yang nantinya akan mengakibatkan terjadinya LM. ${ }^{11,16}$ Penelitian akhir-akhir ini juga mendapatkan hubungan yang kuat antara LM dengan gastresophageal reflux disease (GERD) dan laringopharingeal refluks (LPR), Studi menunjukkan hampir $80 \%$ pasien LM juga mengalami refluks, tetapi hal ini masih menjadi perdebatan apakah penyakit refluks ini mengakibatkan LM/ LPR atau akibat tekanan negatif intratoraks pada pasien LM yang memicu refluks dan memperparah edema laring. ${ }^{11}$

\section{Imaturitas Neuromuskular}

Teori lain yang menjelaskan terjadinya LM ini adalah peran dari lemahnya kontrol neuromuskular yang mengakibatkan hipotonus relatif pada otot dilator supraglotis yang mengakibatkan stuktur supraglotis akan kolaps dan tertutup. ${ }^{1}$ Kelainan pada nervus Vagus akan mengakibatkan menurunnya tonus laring sehingga terjadi kolaps struktur laring dan gangguan mekanisme menelan yang memicu obstuksi jalan nafas dan gangguan menelan. Hal ini terjadi akibat tidak berkembangnya sistem saraf pusat, terutama nervus perifer dan batang otak yang berperan dalam mengontrol pernafasan dan menjaga patensi jalan nafas. Refleks laryngeal adductor merupakan refleks nervus vagus yang berperan dalam fungsi laring dan fonasi. Aktivasi serabut aferen dari saraf ini diperantarai oleh nervus Laringeus superior yang terletak di lipatan ariepiglotis. Rangsangan pada saraf ini kemudian diteruskan ke nukleus batang otak dan memerintahkan serabut motorik untuk mengatur pernafasan dan menelan. Adanya kelainan pada jalur neuromuskular ini diduga menjadi etiologi terjadinya laringomalasia serta keluhan dalam makan. ${ }^{4}$

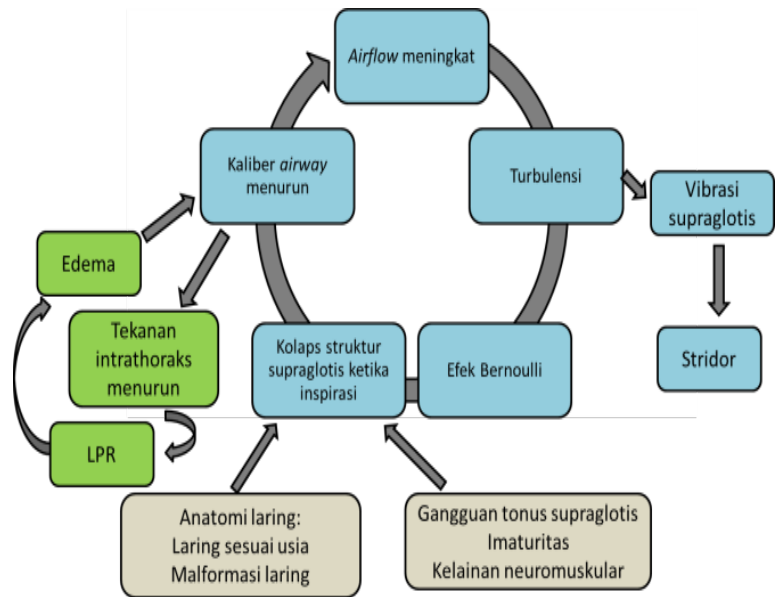

Gambar 2. Etiopatogenesis laringomalasia ${ }^{16}$

\section{Diagnosis}

Diagnosis LM didapatkan dari anamnesis, pemeriksaan fisik dan konfirmasi dengan pemeriksaan flexible fibreoptic laryngoscopy (FFL) dalam keadaan sadar. ${ }^{3,4,9,10}$ Gejala klasik LM adalah didapatkannya stridor inspirasi yang makin berat ketika pasien gelisah, menangis, menyusu, makan dan tidur terlentang..$^{8-10}$ Hal lain yang perlu didapatkan adalah riwayat kelahiran pasien diantaranya berat dan panjang badan saat lahir, usia kehamilan saat lahir, kelainan genetik atau penyakit komorbid lainnya. Pada pemeriksaan fisik yang diperlukan adalah berat dan panjang anak saat pemeriksaan, suara nafas saat inspirasi dan ekspirasi, 
gerakan dada untuk menilai adanya retraksi atau pectus excavatum, serta penilaian perfusi jaringan. ${ }^{9}$

Pemeriksaan FFL dilakukan dalam keadaan tanpa sedasi dengan posisi pasien duduk tegak lurus dipangkuan orang tua, skope dimasukkan melalui lobang hidung, dinilai kelainan yang terdapat pada nasofaring, orofaring, hipofaring dan struktur laring. Pada pemeriksaan FFL ini dapat diamati pergerakan dinamis dari struktur laring selama pernafasan spontan dan bisa membedakan laringomalasia dengan penyebab lain stridor inspirasi seperti paralisis pita suara atau kista laring. Kolaps jaringan supraglotik dan obstruksi selama inspirasi merupakan patognomonis laringomalasia .6,9 Pada laring akan didapatkan prolap kartilago aritenoid, mukosa supra-aritenoid, dan kartilago epiglotis selama inspirasi, pemendekan lipatan aritenoid dan epiglotis selama inspirasi, gambaran tubular shaped epiglotis serta edema posterior glotis (gambar 3).4,9,16,17

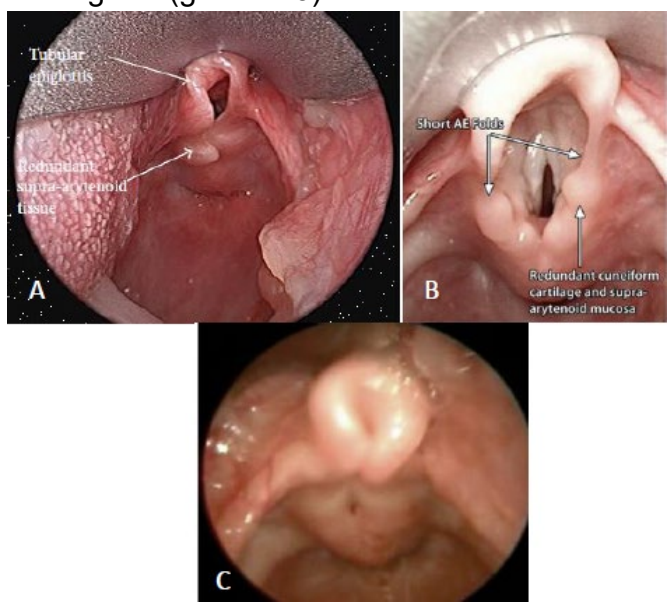

Gambar 3. Laringomalasia.A.Tubular epiglotis dan aritenoid redundant B.Pemendekan lipatan ariepiglotis C.Prolaps mukosa aritenoid saat inspirasi. 6,9

\section{Klasifikasi Laringomalasia}

Terdapat beberapa klasifikasi LM Berdasarkan beratnya penyakit, LM dibagi atas derajat ringan, sedang dan berat. Pembagian derajat ini berdasarkan terdapat atau tidaknya gejala yang berhubungan dengan gangguan dalam menelan makanan serta gejala obstruktif saluran nafas atas.1,4,10

Laringomalasia derajat ringan terdapat stridor inpirasi dan gejala yang berhubungan dengan gangguan dalam menelan saat pasien makan seperti batuk, tersedak dan regurgitasi. Obstruksi saluran nafas pasien derajat ringan tidak akan menyebabkan hipoksia, saturasi oksigen berkisar antara 98-100\%. Sekitar $40 \%$ pasien merupakan LM derajat ringan. Laringomalasia derajat sedang terdapat stridor inspirasi yang semakin jelas dan gejala saluran nafas yang berhubungan dengan makan semakin berat, terdapat sianosis saat makan dan penurunan saturasi oksigen $\leq$ $96 \%$, sekitar $40 \%$ pasien merupakan LM derajat sedang. . $^{1,4,10}$

Pasien LM derajat berat mempunyai 8 tanda primer, yaitu: 1.stridor inspirasi, 2.retraksi suprasternal, 3.retraksi substernal, 4.kesulitan dalam makan, 5.tersedak, 6.muntah setelah makan, 7.gangguan tumbuh kembang dan 8.sianosis. Pasien akan mempunyai saturasi oksigen $\leq 86 \%$ (tabel 1 ). Sebanyak 10-20 \% pasien merupakan LM derajat berat dan membutuhkan tindakan pembedahan untuk mengurangi obstruksi saluran nafas atas. 1,4,10

Tabel 1. Skala Derajat Laringomalasia. ${ }^{9}$

\begin{tabular}{|c|c|c|}
\hline Derajat & Gejala Pernafasan & Gejala Makan \\
\hline Ringan & $\begin{array}{l}\text { Stridor inspirasi } \\
\mathrm{SpO}_{2} 98-100 \%\end{array}$ & $\begin{array}{l}\text { Kadang batuk } \\
\text { atau regurgitasi }\end{array}$ \\
\hline Sedang & $\begin{array}{l}\text { Stridor inspirasi } \\
\text { Saturasi } \mathrm{O}_{2} \leq 96 \%\end{array}$ & $\begin{array}{l}\text { Sering } \\
\text { regurgitasi atau } \\
\text { keluhan } \\
\text { berhubungan } \\
\text { dengan makan }\end{array}$ \\
\hline Berat & $\begin{array}{ll}\text { Stridor } & \text { inspirasi } \\
\text { dengan } & \text { sianosis } \\
\text { atau apnea } & \\
\mathrm{SpO}_{2} \leq 86 \% & \end{array}$ & $\begin{array}{l}\text { Gagal tumbuh } \\
\text { kembang atau } \\
\text { aspirasi }\end{array}$ \\
\hline
\end{tabular}

Berdasarkan anatomi yang terlibat, Olney ${ }^{18}$ pada tahun 1999 mengklasifikasikan LM menjadi 3 tipe yaitu: 1.kolaps posterior jika yang terlibat mukosa aritenoid redundant atau kartilago cuneiform, 2.kolaps lateral jika terjadi pemendekan lipatan ariepiglotis, 3.kolaps anterior jika terjadi epiglotis retrofleksi (gambar 4).
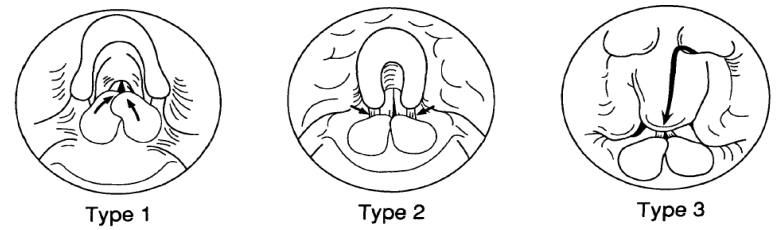

Gambar 4. Tipe Laringomalasia ${ }^{18}$

\section{Penyakit Komorbid}

Terdapat beberapa kelainan atau penyakit komorbid pada pasien laringomalasia yang merupakan penyulit dan menjadikan klinis laringomalasia lebih berat diantaranya:

\section{Gastroesofageal dan Laringofaringeal Refluks} (GERD dan LPR)

Pada pasien LM sekitar 65-100\% terdapat GERD, hal ini diakibatkan oleh obstruksi saluran nafas pada pasien LM akan mengakibatkan tekanan negatif intratoraks yang akan memicu refluks asam lambung ke daerah laringofaringeal yang akan mengakibatkan iritasi mukosa sekitar laring dan faring sehingga mukosa akan edema. Edema mukosa ini akan memperparah obtruksi saluran nafas pada pasien LM sehingga memperparah gejala. Adanya paparan asam lambung yang terus menerus ini akan mengakibatkan penurunan refleks dalam menelan, sehingga hal ini akan mengakibatkan timbulnya gejala tersedak dan terbatuk ketika makan. .,9 $^{4}$

\section{Penyakit Neurologis}

Kelainan neurologis terdapat pada $20-45 \%$ pasien LM diantaranya :kejang, hipotonus, gangguan 
perkembangan, cerebral palsy, retardasi mental, mikrosefalus, Quadriparese dan malformasi Chiari. ${ }^{4}$ Pada pasien dengan kelainan neurologis ini akan terjadi penurunan fungsi nervus vagus yang berperan dalam proses menelan sehingga terjadi penurunan tekanan laring yang nantinya akan bermanifestasi sebagai keluhan saluran nafas yang berhubungan dengan makan. ${ }^{4,9}$

\section{Lesi Sekunder Saluran Nafas}

Lesi sekunder saluran nafas atau Synchronous Airway Lession (SAL) terdapat pada 7,5 - 64\% LM. Jenis SAL yang sering ditemukan adalah stenosis subglotis, trakeomalasia dan paralisis pita suara. ${ }^{19}$ Kelainan ini dapat dideteksi dengan airway fluoroscopy untuk trakeomalasia atau dengan pencitraan radiografi resolusi tinggi untuk lesi struktural seperti stenosis subglotis. Pemeriksaan standar untuk mengetahui adanya SAL ini adalah menggunakan FFL ataupun bronkoskopi kaku dibawah general anestesia. Pemeriksaan FFL baik dalam mendeteksi adanya lesi dinamis, sebaliknya bronkoskopi kaku lebih baik dalam melihat adanya lesi statis seperti stenosis subglotis. Adanya kelainan ini nantinya akan memperberat obstruksi saluran nafas dan akan memicu terjadinya refluks asam lambung yang kemudian menambah progresivitas LM.4,9,10

\section{Penyakit Jantung Bawaan (PJB)}

Penyakit ini terdapat pada $10 \%$ pasien LM, ditemukan pada LM derajat sedang-berat. Adanya sumbatan jalan nafas akan memperberat penyakit jantung dan memperberat klinis LM. Sebanyak $34 \%$ pasien LM dengan PJB memerlukan tindakan pembedahan. ${ }^{4,9}$

\section{Anomali Kongenital/Sindroma/ Kelainan Genetik}

Kelainan ini didapatkan pada $8-20 \%$ LM dan $40 \%$ pasien LM derajat berat. Pasien dengan anomali kongenital hampir selalu mempunyai SAL, PJB dan kelainan neurologis yang memperberat oksigenasi dan penafasan. Sindroma Down merupakan kelainan yang paling sering ditemukan. Kelainan lain diantaranya adalah micrognathia (sindroma CHARGE) dan sindroma Pierre Robin. ${ }^{4,9}$

\section{Penatalaksanaan}

Dalam penatalaksanaan pasien LM, perlu diperhatikan berat dan ringannya gejala saat pertama didiagnosis, adanya faktor komorbid serta adanya perbaikan atau perburukan gejala setelah terapi awal. Penatalaksanaan LM dibagi atas terapi konservatif dan tindakan pembedahan.

\section{Konservatif}

Terapi konservatif merupakan terapi pilihan pada pasien LM derajat ringan dan sedang tanpa keluhan yang berhubungan dengan makan. Pasien harus dikontrol dan observasi tumbuh kembang serta keluhan saluran nafas yang berhubungan dengan makan. Jika terdapat sedikit keluhan makan, terapi konservatif dengan posisi makan tegak lurus, asupan sedikit-sedikit dan sering dengan ASI atau formula yang dipadatkan, dan medikamentosa untuk mencegah refluks asam lambung. ${ }^{9}$ Lansoprazole $7,5 \mathrm{mg}$ sekali sehari dan domperidone $(1 \mathrm{mg} / \mathrm{kg} / \mathrm{hari})$ bisa digunakan sebagai terapi anti refluks asam lambung. ${ }^{1}$

\section{Pembedahan}

Tindakan pembedahan dilakukan pada semua pasien LM derajat berat, pasien LM derajat ringan atau sedang yang mempunyai penyakit komorbid seperti trakeomalasia atau stenosis subglotis atau pasien yang gagal dengan terapi konservatif, pasien laringomalasia yang gagal tumbuh kembang dan riwayat aspirasi berulang (tabel 2).4,9 Pada pasien yang akan dilakukan tindakan pembedahan, sebelum dilakukan tindakan sebaiknya pasien diberikan antagonis reseptor $\mathrm{H}_{2}$ dosis tinggi ( $3 \mathrm{mg} / \mathrm{kgBB}$ ) atau PPI sekali sehari. Beberapa jenis tindakan pembedahan untuk LM adalah : supraglotoplasti dan epiglotoplasti. Pemilihan jenis operasi berdasarkan tipe LM berupa supraglotoplasti dengan melakukan eksisi mukosa aritenoid redundant pada tipe I, insisi lipatan ariepiglotis yang memendek pada tipe II dan epiglotoplasti pada LM tipe III (gambar 6).5,6,18

Tabel 2. Indikasi Klinis Untuk Pembedahan. ${ }^{9}$

\begin{tabular}{|c|c|}
\hline Pernafasan & Makan \\
\hline $\begin{array}{ll}\text { - } & \text { Stridor dengan } \\
\text { stress } \\
\text { pernafasan } \\
\text { - } & \text { Dispneu dengan } \\
\text { retraksi } \\
\text { - } & \text { Pectus } \\
\text { excavatum } \\
\text { - } & \text { Cor pulmonale } \\
\text { Obstructive sleep } \\
\text { apneu berat }\end{array}$ & $\begin{array}{ll}\text { - } & \text { Sianosis } \\
\text { berulang ketika } \\
\text { makan } \\
\text { - } & \text { Aspirasi } \\
\text { pneumonia } \\
\text { berulang } \\
\text { - } \\
\begin{array}{l}\text { Gagal tumbuh } \\
\text { kembang }\end{array}\end{array}$ \\
\hline
\end{tabular}
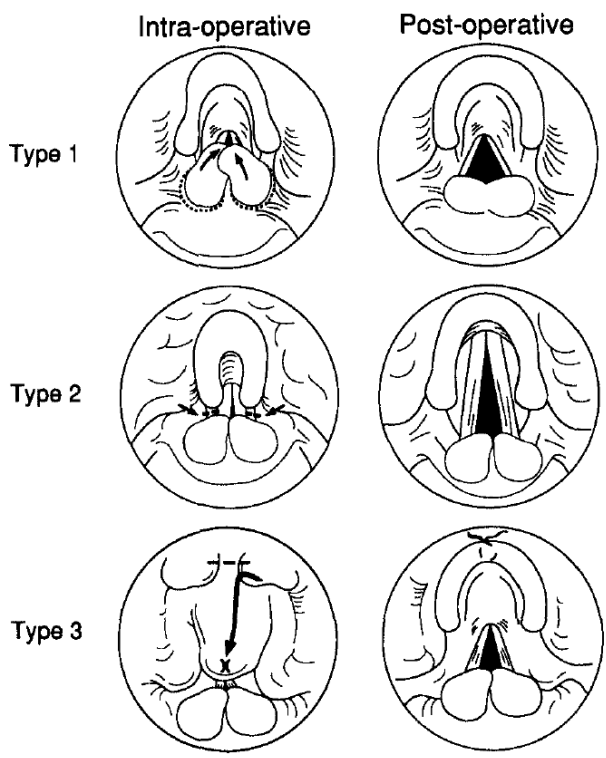

Gambar 6. Pilihan Pembedahan sesuai tipe Laringomalasia. ${ }^{18}$

Supraglotoplasti pertama kali dikenalkan tahun 1922 dan menjadi tindakan pilihan untuk mengobati LM menggantikan tindakan trakeostomi yang merupakan satu-satunya pilihan terapi 
sebelumnya, sekarang pilihan operasi beragam pada setiap pasien sesuai anatomi dan fungsi yang terganggu. 2,20 Tindakan trakeostomi sekarang ini jarang dilakukan pada pasien dengan LM saja. Trakeostomi dilakukan pada pasien LM dengan $>3$ penyakit komorbid, sleep apneu berat yang tercatat dalam sleep study dan keluhan yang menetap setelah dilakukan supraglotoplasti. ${ }^{11}$ Tindakan supraglotoplasti pada LM dengan lipatan ariepiglotis yang pendek, maka dilakukan reseksi mukosa baik menggunakan gunting mikro, laser atau mikrodebrider. Pada mukosa aritenoid redundant atau kartilago cuneiformis dilakukan reseksi lipatan ariepiglotis yang diperluas sampai ke permukaan sisi lateral epiglotis. ${ }^{2}$ Secara umum Supraglotoplasti ini dibagi atas:

(1).Pemisahan lipatan ariepiglotis unilateral, (2).Pemisahan lipatan ariepiglotis bilateral,

(3).Pemisahan lipatan ariepiglotis bilateral dengan pengangkatan jaringan aritenoid redundant unilateral dan (4). Pemisahan komplit bilateral (gambar 7). ${ }^{21}$

Pada kebanyakan pasien LM, obstruksi laring akibat prolap aritenoid dan pemendekan lipatan ariepiglotis dapat diatasi dengan supraglotoplasti, tetapi pada kasus LM dengan etiologi kolaps epiglotis selama inspirasi, terdapat 2 pilihan tindakan pembedahan berupa epiglotektomi parsial dan glossoepiglotopeksi. ${ }^{2,6,20}$

Bartolomeo $^{22}$ melakukan tindakan epiglotektomi parsial berbentuk $\mathrm{V}$ dengan menggunakan laser $\mathrm{CO}_{2}$. Tindakan ini bertujuan untuk mengurangi kolapsnya epiglotis kedalam laring selama inspirasi (gambar 8).
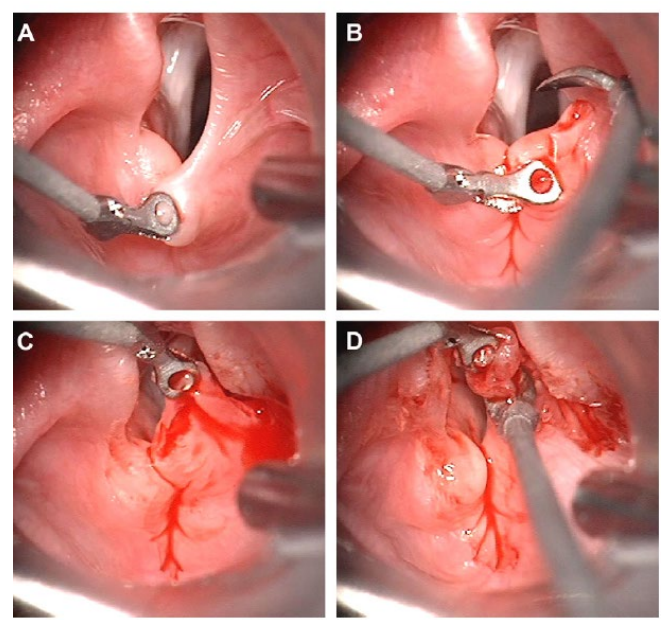

Gambar 7. Reseksi lipatan ariepiglotis dan jaringan supraaritenoid. ${ }^{6}$

Glossoepiglotopeksi dilakukan dengan penjahitan tepi bilateral epiglotis ke pangkal lidah menggunakan benang absorbable yang bertujuan untuk membuat permukaan lingual epiglotis menempel ke pangkal lidah sehingga hal ini akan menjaga patensi saluran nafas dan kemampuan berbicara, tetapi terdapat kemungkinan gangguan dalam makan dan aspirasi pasca operasi. ${ }^{6,20}$

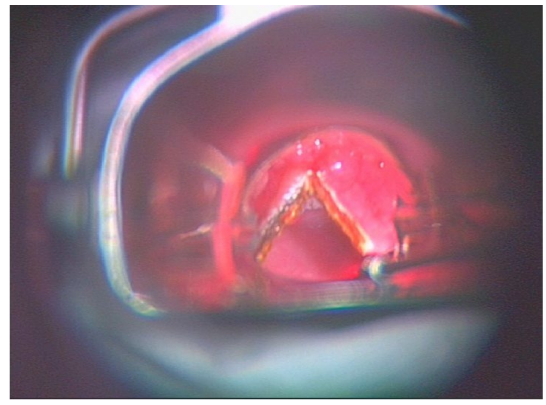

Gambar 8. Epiglotektomi parsial. ${ }^{22}$

Whymark $^{6}$ melakukan epiglottopeksi pada $73 \%$ dari 58 bayi dengan LM derajat berat dimana didapatkan perbaikan stridor dan peningkatan berat badan pasien pasca operasi. Dilakukan ablasi mukosa lingual epiglotis dan mukosa pangkal lidah menggunakan laser $\mathrm{CO}_{2}$, kemudian epiglotis dan pangkal lidah dijahit menggunakan benang absorbable (gambar 9).

Pada tindakan ini, tidak satupun pasien yang didapatkan komplikasi aspirasi pasca operasi. Trakeostomi sebagai life saving dilakukan pada pasien LM dengan obstruksi jalan nafas yang mengancam nyawa serta pasien yang tidak terdapat perbaikan setelah tindakan supraglotoplasti. 2,4

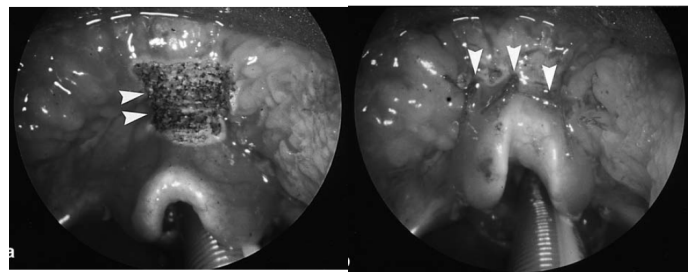

Gambar 9. Epiglotopeksi A. eksisi mukosa dasar lidah dan permukaan lingual epiglotis menggunakan Laser $\mathrm{CO}_{2}$ B. Epiglotis setelah difiksasi ke pangkal lidah. ${ }^{5}$

\section{Perawatan Pasca Operasi}

Setelah tindakan operasi, setiap pasien dirawat di ruang intensif sampai memungkinkan untuk dirawat di ruang rawat biasa. Pasien diberikan terapi antirefluks (PPI 2xsehari) dan tidur dengan posisi elevasi kepala untuk mengurangi edema dan pembentukan granuloma pada mukosa yang dioperasi akibat paparan asam lambung. Pasien juga diberikan steroid $0,5 \mathrm{mg} / \mathrm{kgBB}$ untuk mengurangi edema dan obstruksi jalan nafas pasca operasi. ${ }^{9}$ Pasien dapat di ekstubasi setelah operasi atau sehari setelah operasi, tergantung dari beratnya penyakit dan usia pasien. Setelah pasien sadar penuh, dapat dilakukan pemberian makan seperti biasa, atau pemasangan nasogastric tube diperlukan pada pasien dengan riwayat aspirasi berat. Setelah pasien bisa diekstubasi dan tidak ada tanda-tanda stress pernafasan, dan bisa makan dengan baik pasien diperbolehkan pulang dan kontrol rawat jalan. Perlu dilakukan evaluasi berat badan, keluhan pernafasan, sleep apneu dan pemeriksaan FFL untuk menilai struktur laring, penyembuhan luka operasi serta pembentukan jaringan parut. Pada pasien dengan perbaikan keluhan, pemerikasaan FFL ini perlu dilakukan pada bulan 
pertama dan ketiga setelah operasi untuk menilai LPR, obstruksi jalan nafas dan gangguan makan. ${ }^{6}$

\section{Diagnosis Banding}

Laringomalasia merupakan penyebab tersering stridor inspirasi pada anak. Terdapat beberapa peyakit dan keadaan yang menimbulkan stridor inspirasi pada anak diantaranya adalah: 1. penyakit croup (laringotrakeobronkitis) yang diakibatkan oleh infeksi virus parainfluenza virus, influenza virus tipe $A$ atau rhinovirus, 2. Epiglottitis yang merupakan infeksi bakteri Haemophilus influenza tipe B, Streptococcus beta haemolitikus, staphylococcus dan pneumococcus pada epiglotis, 3. Trakeitis yang merupakan infeksi akut bakteri pada trakea, 4. Aspirasi benda asing yang merupakan keadaan yang dapat mengancam nyawa dengan onset akut batuk-batuk hebat,tersedak serta rasa tercekik, 5. Hemangioma subglotis, 6.stenosis subglotis, 7.paralisis pita suara dan 8.trakeomalasia. ${ }^{23}$

\section{SIMPULAN}

Laringomalasia merupakan penyebab stridor inspirasi tersering pada bayi. Diagnosis didapatkan dari anamnesis, pemeriksaan fisik dan pemeriksaan penunjang FFL dimana didapatkan gambaran kolapsnya strukstur supraglotis selama inspirasi. Klasifikasi LM berdasarkan beratnya gejala serta anatomi yang terlibat. Pada LM derajat ringan dan sedang, terapi konservatif dengan medikamentosa, modifikasi perawatan dan observasi keluhan merupakan pilihan utama. Sebagian besar kasus akan resolusi dalam 2 tahun. Laringomalasia derajat berat serta adanya faktor komorbid merupakan indikasi dilakukan tindakan pembedahan. Supraglotoplasti merupakan tindakan pembedahan pilihan untuk LM dengan angka keberhasilan yang tinggi. Trakeostomi sekarang ini sangat jarang dilakukan pada pasien LM. Pemberian PPI sangat dianjurkan baik sebelum atau setelah tindakan pembedahan.

\section{DAFTAR PUSTAKA}

1. Fattah HA, Gaafar AH. Laryngomalacia: Diagnosis and management. Egypt J Ear, Nose, Throat Allied Sci. 2012;12(3):149-153.

2. Netto JFL, Drummond RL, Oppermann P, Hermes FS, Krumenauer RCP. Laryngomalacia surgery: a series from a tertiary pediatric hospital. Braz $J$ Otorhinolaryngol. 2012;78(6):99-106.

3. Technique ANS. Atypical Presentation of Severe Laryngomalacia Managed with Aryepiglottoplasty and A Novel Suture Technique. J Med Sci Clin Res. 2017;5(6):23282-23287.

4. Landry AM, Thompson DM. Laryngomalacia: Disease Presentation, Spectrum, and Management. Int J Pediatr. 2012:1-6.

5. Werner JA, Lippert BM, Dunne AA, Ankerman T, Folz BJ, Seyberth H. Epiglottopexy for the treatment of severe laryngomalacia. Eur Arch OtoRhino-Laryngology. 2002;259(9):459-464.

6. Richter GT, Thompson DM. The Surgical Management of Laryngomalacia. Otolaryngol Clin North Am. 2008;41:837-864.
7. Saputri RAH, Sudiro M, Wijana SSR. Gambaran Klinis Pasien Laringomalasia di Poliklinik Telinga Hidung Tenggorok Bedah Kepala Leher Rumah Sakit Dr . Hasan Sadikin Bandung Periode Januari 2012 - Maret 2015. Tunas Med J Kedokt dan Kesehat. 2016;3(1):1-6.

8. Pinto JA, Wambier H, Mizoguchi El, Gomes LM. Surgical treatment of severe laryngomalacia: a retrospective study of 11 cases. Braz J Otorhinolaryngol. 2013;79(5):564-568.

9. Thorne MC, Garetz SL, Thorne MC, Garetz SL. Laryngomalacia: Review and Summary of Current Clinical Practice in 2015. Paediatr Respir Rev. 2016;17:3-8.

10. Thompson DM. Laryngomalacia: factors that influence disease severity and outcomes of management. Curr Opin Otolaryngol Head Neck Surg. 2010;18:564-570.

11. Pamuk AE, Süslü N, Günaydın RÖ, Atay G, Akyol $U$. Laryngomalacia: patient outcomes following aryepiglottoplasty at a tertiary care center. Tourkish J Pediatr. 2013;55:524-528.

12. Sasaki CT, Kim YH. Anatomy and Physiology of the Larynx. In: Ballenger JJ, Snow JB, eds. Ballenger's Otorhinology Head \& Neck Surgery. 17th ed. Spain: Decker BC; 2008:847-858.

13. Johnson JT, Rosen CA. Upper Airway Anatomy and Fuction. In: Gayle WE, ed. Bailey Head \& Neck Surgey Otolaryngology. V. Philadelphia: Lippincott Williams \& Wilkins; 2014:868-878.

14. Collins SR. Direct and Indirect Laryngoscopy: Equipment and Techniques. Respir Care. 2014;59:850-864.

15. Piazza C, Ribeiro JC, Bernal-Sprekelsen M, Paiva A, Peretti G. Anatomy and Physiology of the Larynx and Hypopharynx. In: Anniko M, BernalSprekelsen M, Bonkowsky V, Bradley PJ, lurato S, eds. Otorhinolaryngology, Head and Neck Surgery. Berlin, Heidelberg: Springer Nature, 2010:461-471.

16. Ayari S, Aubertin G, Girschig H, Abbeele $T$ Van Den, Mondain M. Pathophysiology and diagnostic approach to laryngomalacia in infants. Eur Ann Otorhinolaryngol Head Neck Dis. 2012;129(5):257-263.

17. Rastatter JC, Jr JWS, Hoff SR, Holinger LD. Aspiration before and after Supraglottoplasty regardless of Technique. Int $J$ Otolaryngol. 2010:5-9.

18. Olney DR, Greinwald H, Smith RJH, Bauman NM. Laryngomalacia and Its Treatment. Laryngoscope. 1999;(November):1770-1775.

19. Benoit M. Secondary Airway Lesions in Laryngomalacia: Head and Neck Surgery. Otolaryngol Head Neck Surg. 2011;144(2):269273.

20. Dias R, Deshmukh CT, Tullu MS, Divecha C, Karande S. Rare treatment option for a common pediatric airway problem. Indian J Crit Care Med. 2015;19(11):61-63.

21. Camacho M, Dunn B, Torre C, Sasaki J, Gonzales R, Liu SY, et al. Supraglottoplasty for Laryngomalacia with Obstructive Sleep Apnea: A Systematic Review and Meta-Analysis. Laryngoscope. 2016;126:1246-1255.

22. Bartolomeo $M$, Bigi $A$, Pelliccia $P$, Makeieff $M$. Surgical treatment of a case of adult epiglottic laryngomalacia. Eur Ann Otorhinolaryngol Head Neck Dis. 2015;132(1):45-47. 
23. Daniel M, Cheng A. Neonatal Stridor. Int J Pediatr 2012:1-5. 